〔47〕アルキルビニルエーテルの低温カチオン重合および 生成ポリマーの性質に関する研究

第 7 報 メチルおよびエチルエーテルの重合条件とポリマー性質との関係

(1961 年 1 月 23 日受理)

児玉恒雄* ・東村敏延* ・岡村誠三*

\begin{abstract}
要旨 $\quad \mathrm{BF}_{3} \cdot \mathrm{O}\left(\mathrm{C}_{2} \mathrm{H}_{5}\right)_{2}$ を触媒とするメチルビニルエーテル $(\mathrm{MVE})$ 㧍よびエチルビニルエーテル (EVE) の均一系カチオン機構による立体特異性重合を研究した。生成ポリマーの立体規則性の判定は㳄化点 の測定により行なった。反応系の誘電摔の増加拉よび重合温度の上昇は生成ポリマーの立体規則性を減少す る。MVEでは低誘電率溶媒中で低モ/マー濃度で重合を行なうと, 従来報告されている方法で得られたポリ マーよりも立体規則性のすぐれたポリマーの得られることが明らかとなった。また EVE は軟化点の高いポリ マーでも X 線図的には結晶化しない。これは立体規則性の良いポリマーでも結晶化しにくい場合があるとする 説明が妥当なようである。MVEでは重合温度と生成ポリマーの結晶化度から isotactic 付加と syndiotactic 付加のそれぞれの生長反応に执ける活性化エネルギーの差を推定する方法を吟味し, それより反応機構につい て若干の考察を行なった。
\end{abstract}

\section{1. 緒言}

側鎖の異なるアルキルビニルェーテルは同一条件で重 合しても，生成ポリマーの結晶性汇著しい差があること を前報》で報告した。それ㠴えここでは結晶性ポリマー の得られやすいメチルビニルェーテル (MVE) およびそ うでないェチルビニルェーテル (EVE) について, 重合 条件（主として溶媒の種類と重合温度）と生成ポリマー の立体規則性および結晶性との関係を検討した。また MVE については, 重合条件と生成ポリマーの絬晶化度 より立体規則性重合の活性化エネルギーに関する数値を 推定し，均一系カチオン重合に扔咅体特異性重合の 機構についても若干の考察を行なった。

\section{2. 実験}

\section{1 重合操作}

MVE については第 1 報2で述べたと全く同様に試料 の精製, 重合およびポリマーの精製を行なった。EVE については操作はすべて前報1で述べたように MVEと 同じであるが，ポリマーの沈殿骩として水を使用した。 生成ポリマーの重合度は $30^{\circ} \mathrm{C}$, ベンゼン溶液の極限粘度 数 $[\eta](100 \mathrm{ml} / \mathrm{g})$ で比較した。

\section{2 ポリマーの軟化点}

ポリマーの軟化点の測定は, いわゆる penetration $\operatorname{method}^{3)}$ により測定した。先端の直径が $0.155 \mathrm{~cm}$ のス テンレススチールの棒を, 細いガラス管中に採取したポ リマーの上に置き, $0.2^{\circ} \mathrm{C} / \mathrm{min}$ の速度でポリマーの温度 を上昇せしめた。各温度ごとに試料の上にのせた棒の動 きをカセトメーターで追跡し，棒の急激に落下する温度 を顿化点とした。この測定において温度上昇速度を

\footnotetext{
* 京都大学工学部䋐維化学教室(京都市左京区吉田本町)
}

$0.1^{\circ} \mathrm{C} / \mathrm{min} \sim 1.0^{\circ} \mathrm{C} / \mathrm{min}$ の間を変化したが，軟化点は約 $2^{\circ} \mathrm{C}$ 異なるのみであったので, ここでは上記の速度で温 度を変化せしめた。軟化点はまた渮重(棒の重さ)によっ て変化するが,ここでは $27 \mathrm{~g}$ のものを使用した。

軟化点はポリマーの立体構造のみでなくその重合度に よっても変化する。そ杉えここで求めた軟化点と重合 度の関倸を検討した。試料としては，MVE の重合に掠 いて反応系にメタノールを添加して立体規則性は同一と 考えられるが, 分子量が異なるポリマーを使用した(この 関係はイソブチルビニルェーテルで明確に求められてい $ろ^{4)}$ )。Fig. 1 にみられるようにメタノールの添加は生成 ポリマーの $\left[\eta^{2}\right]$ を著しく低下せしめるが，軟化点はほと んど変化しない。したがって軟化点はこの範囲の $[\eta] の$

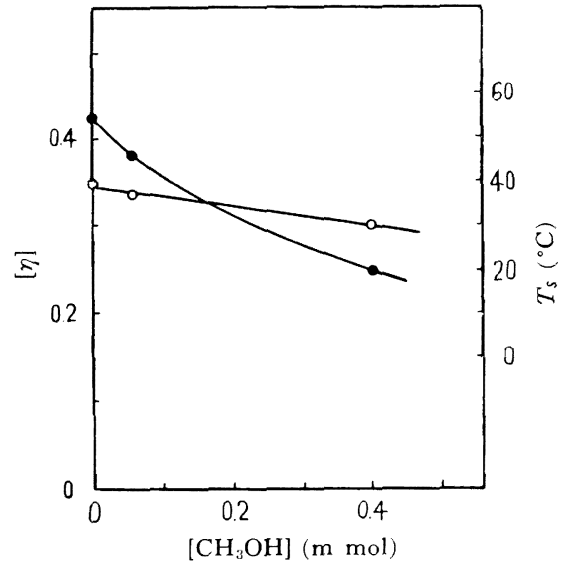

MVE: 20 vol $\%$, Toluene: 80 vol $\%, \mathrm{BF}_{3} \cdot \mathrm{O}$

$\left(\mathrm{C}_{2} \mathrm{H}_{5}\right)_{2}$ catalyst, Temperature: $-78^{\circ} \mathrm{C}$,

: $[\eta], O: T_{S}$

Fig. 1 Effect of chain transfer agent $\left(\mathrm{CH}_{3} \mathrm{OH}\right)$ 
ポリマーでは立体規則性にのみ依存するものと考えられ る。

軟化点は一般に二次転移点と融点の間の值をとるとさ れているが, 測定方法により軟化点の定義 (軟化点とみな される試料の変形の度合)を異にするので, 軟化点として 得られる数值も測定方法によって異なり, 二次転移点に 近い值のものから融点に近い值のものまで広範囲にわた っている。したがって適当な方法を使用すれば, 軟化点 は二次転移点あるいは融点の代用手段として十分比較で きると考えられる5)。

本実験で採用した penetration method は, 試料の変 形の比較的大きいところで軟化点を定義した測定方法で ある。したがってこの方法で得られた軟化点は融点に近 い值を示すと考えられる。事実, 二三の結晶性試料につ いて軟化点と偏光顕微鏡による融点を比較したところ, その差は約 $10^{\circ} \mathrm{C}$ (融点が軟化点より約 $10^{\circ} \mathrm{C}$ 高い)であ って, 両者の間には平行関係が認められた。

\section{3 軟化点と結晶化度}

厚さ $0.5 \sim 0.7 \mathrm{~mm}$ の皮膜を流延法でベンゼン溶液か ら生成した。この試料について X 線干渉図を計数管に よる走查によって求めた。皮膜形成能を有しない試料に ついては特別の試料台を用いて同じ条件下で測定が行な われた。結晶化度の測定はポリメチルビニルェーテル (PMVE) について桜田研究室で行なわれ, これについて は別に詳細が報告される予定である6)。ここでは $\mathrm{X}$ 線写 真, 流動性その他の理由から, 触媒として $\mathrm{BF}_{8} \cdot \mathrm{O}\left(\mathrm{C}_{2} \mathrm{H}_{5}\right)_{2}$ を用いてモノマー濃度 $20 \mathrm{vol} \%$, トルェン溶液中で -20 $0^{\circ} \mathrm{C}$ に扔いて重合して得たポリマーを $100 \%$ 非晶性 ポリマーと仮定した。

このよらにして得られた結晶化度の大きさの順序と軟 化点の順序は Fig. 2 に示すように定性的に良く一致し ている。それゆえここで求めた軟化点は, ポリマーの結

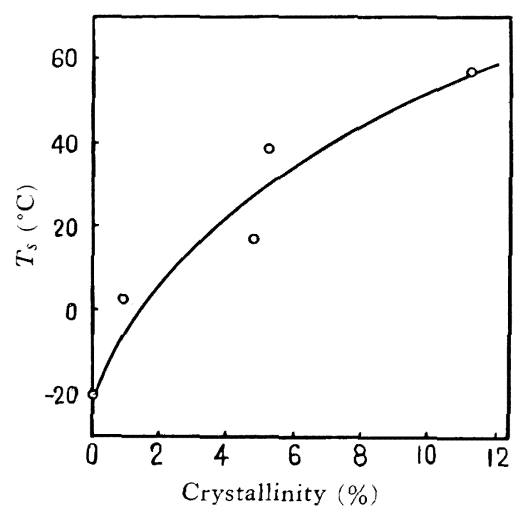

Fig. 2 Relation between crystallinity and softening temperature
晶化度の比較のために 適当な尺度であることがわかっ た。

\section{3. 結 果}

\section{1 溶媒の影響}

均一系イオン機構による立体特異性重合では, 反応系 の誘電率が生成ポリマーの立体規則性に著しい影響を与 えることが知られている4)。それゆえここでも溶媒の誘 電率と生成ポリマーの性質との関倸を検討した。

\section{1 .1 メチルビニルエーテル}

MVE の濃度を一定 (20 vol\%) として, n-へキサン. トルェンおよび塩化メチレンのそれぞれの混合溶媒中で 重合した。得られた結果を Fig. 3 に示した。以前化報 告したように2)，n-へキサンの多、系では重合は容易に 進行せず, 反忘系は不均一である。前報 ${ }^{2}$ では PMVE の立体規則性を比較する適当な手段がまだ不明であっ て，X 線図的に結晶し得るかどうか比較したのみであっ た。しかしここで軟化点を比較することによって, 溶媒 組成と立体規則性の関係が明睹に認められた。

MVE の誘電率は測定されていないので, 溶媒の誘電 率と生成ポリマーの性質との関係を図示したのが Fig. 4 である。これより MVE もイソブチルビニルェーテル (IBVE) と同様に誘電率の増加により生成ポリマーの立 体規則性は著しく減少し, その減少の仕方は誘電率の低 い範囲で著しいことが認められた。

\subsection{2 エチルビニルエーテル}

EVE に扔いても MVE と同様に一定モノマー濃度 (20 vol\%) で，n一へキサンートルエンおよび $n$-へキサンー 塩化メチレン系で重合を行なった。溶媒組成と生成ポリ マーの性質の関倸を Fig. 5 に示した。MVE と同様に 溶媒の極性の大きい系で得たポリマーほど低い軟化点を 示している。この傾向は MVE と同じであるが, EVE では低誘電率系で得た軟化点の高いポリマーでさえも MVE と異なり結晶性の X 線図が得られなかった。

\section{2 モノマー濃度の影響}

溶媒の影響に関する実験からより低誘電率の系で得た ポリマーが立体規則性のすぐれていることが認められ た。それゆえ IBVE の場合と同様に低モノマー濃度に おいて立体規則性のすぐれたポリマーが得られるものと 考えてモノマー濃度の影響を検討した。トルェンを溶媒 とした場合は十分な収率でポリマーが得られなかった が，Fig. 6 に認められるよらにモノマー濃度 $10 \mathrm{vol} \%$ で得たポリマーは $20 \mathrm{vol} \%$ で得たポリマーよりもずっ と高い軟化点を示した。塩化メチレンを溶媒とする場合 もほぼ類似の傾向が認められる。

ここで示したように MVE $10 \mathrm{vol} \%$ ，卜ルェン $90 \mathrm{vol} \%$ の系では立体規則性のきわめて良いと考えられるポリ マーが得られた。この結果よりトルェンまたは $n$-へキ 


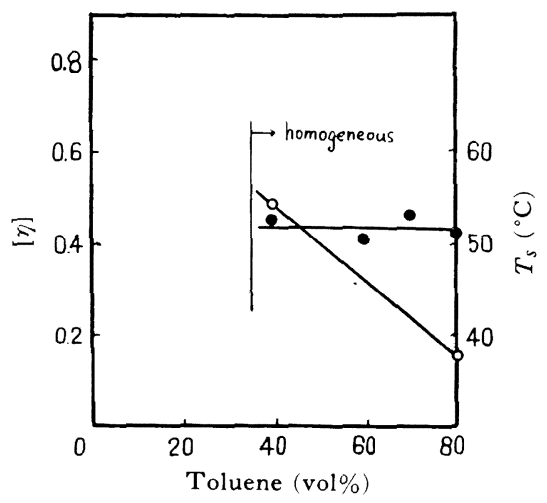

Fig. 3-a

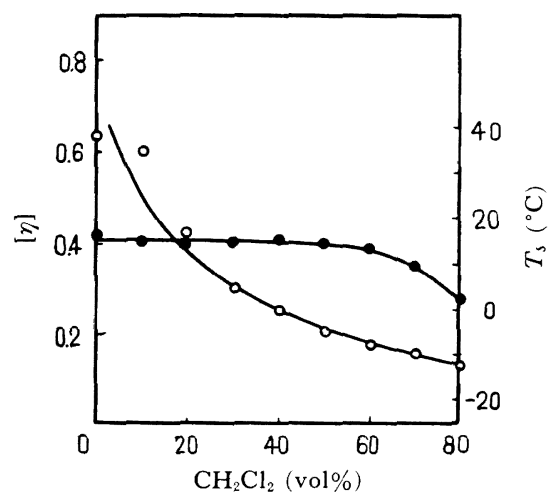

Fig. 3-b

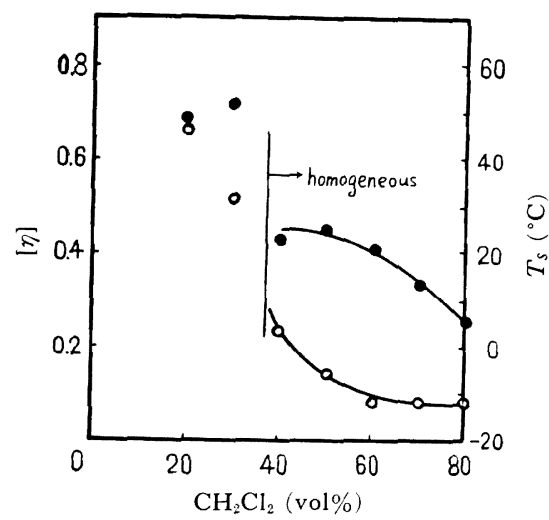

Fig. 3-c

MVE: 20 vol\%, $\mathrm{BF}_{3} \cdot \mathrm{O}\left(\mathrm{C}_{2} \mathrm{H}_{5}\right)_{2}$ catalyst,

Temperature: $-78^{\circ} \mathrm{C}, \bullet:[\eta], \bigcirc: T_{s}$

Solvents: $3-\mathrm{a} \quad n-\mathrm{C}_{6} \mathrm{H}_{14}-\mathrm{C}_{6} \mathrm{H}_{5} \cdot \mathrm{CH}_{3}$

3-b $\mathrm{C}_{6} \mathrm{H}_{5} \cdot \mathrm{CH}_{3}-\mathrm{CH}_{2} \mathrm{Cl}_{2}$

3-c $n-\mathrm{C}_{6} \mathrm{H}_{14}-\mathrm{CH}_{2} \mathrm{Cl}_{2}$

Fig. 3 Effects of solvents on $[\eta]$ and $T_{s}$

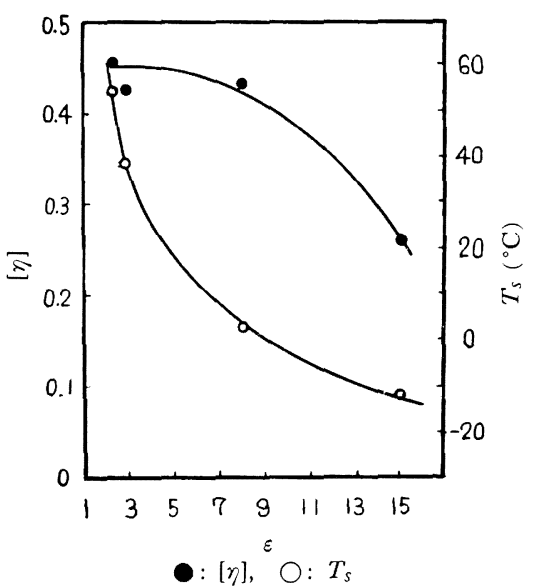

Fig. 4 Relation between dielectric constant and $[\eta]$ or $T_{s}$ (from Fig. 3)

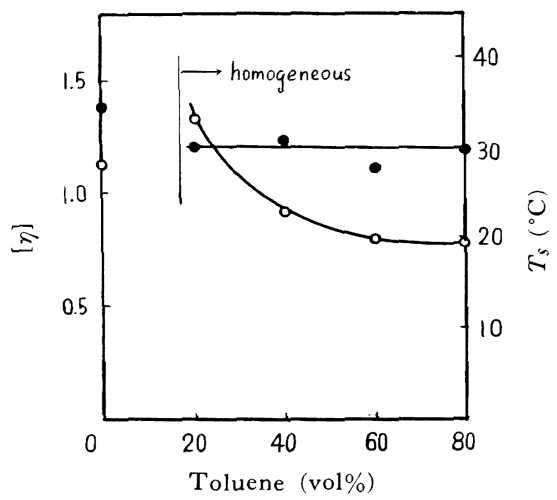

Fig. 5-a

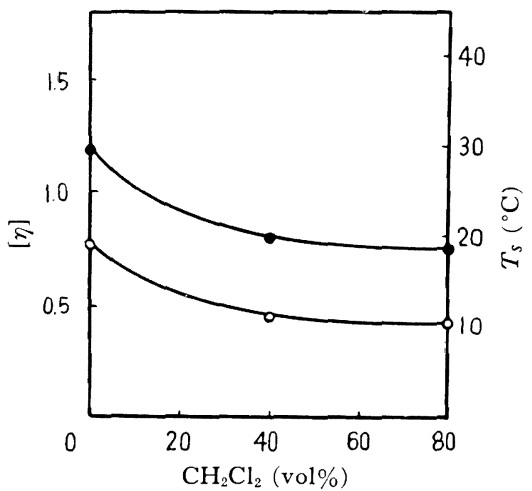

Fig. 5-b

EVE: 20 vol\%, $\mathrm{BF}_{3} \cdot \mathrm{O}\left(\mathrm{C}_{2} \mathrm{H}_{5}\right)_{2}$ catalyst,

Temperature: $-78^{\circ} \mathrm{C},-[\eta], O: T_{S}$

Solvents: 5-a: $n-\mathrm{C}_{6} \mathrm{H}_{14}-\mathrm{C}_{6} \mathrm{H}_{5} \cdot \mathrm{CH}_{3}$ 5-b : $\mathrm{C}_{6} \mathrm{H}_{5} \cdot \mathrm{CH}_{3}-\mathrm{CH}_{2} \mathrm{Cl}_{2}$

Fig. 5 Effects of solvents on $[\eta]$ and $T_{s}$ of PEVE 


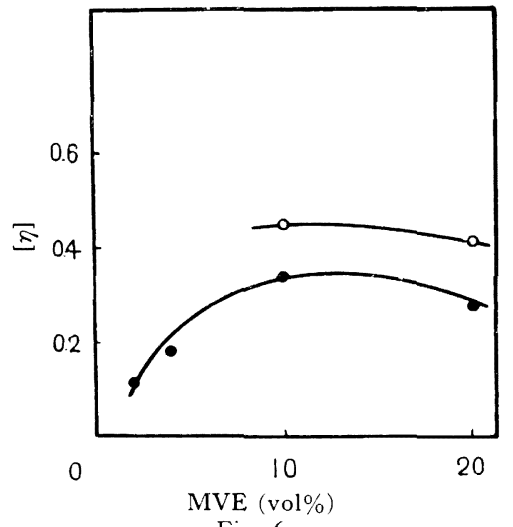

Fig. 6-a

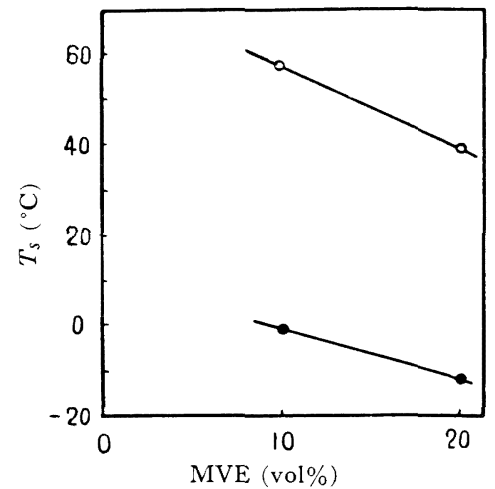

Fig. 6-b

$\mathrm{BF}_{3} \cdot \mathrm{O}\left(\mathrm{C}_{2} \mathrm{H}_{5}\right)_{2}$ catalyst, Temperature: $-78^{\circ} \mathrm{C}$, Solvents; $\mathrm{O}: \mathrm{C}_{6} \mathrm{H}_{5} \cdot \mathrm{CH}_{3}, \mathbf{O}: \mathrm{CH}_{2} \mathrm{Cl}_{2}$

Fig. 6 Effects of monomer concentration on

[ $\eta$ ] Fig. 6-a) and $T_{s}$ (Fig. 6-b)

サンートルェン混合溶媒を用いて低モノマー濃度で重合 ができると，さらに立体規則性のすぐれたポリマーが得 られることが期待される。

\section{3 重合温度の影響}

トルェンを溶媒とする MVEの重合において, 重合温 度の生成ポリマーの性質に対する影響を二三のモノマー 濃度について検討を行なった。Fig. 7 に示すように $[\eta]$ および軟化点とも重合温度の上昇とともに著しく減少し ている。

前に求めた軟化点と結晶化度との関係 (Fig. 2) より, 重合温度と生成ポリマーの結晶化度の関係を示すと Fig. 8 となり, 重合温度と結晶化度の間に一定の関係の あることが認められた。

\section{4. 考 察}

MVE の $\mathrm{BF}_{3} \cdot \mathrm{O}\left(\mathrm{C}_{2} \mathrm{H}_{5}\right)_{2}$ 触媒によるカチオン重合にお いて, 生成 PMVE の立体規則性に及ぼす諸条件が検討

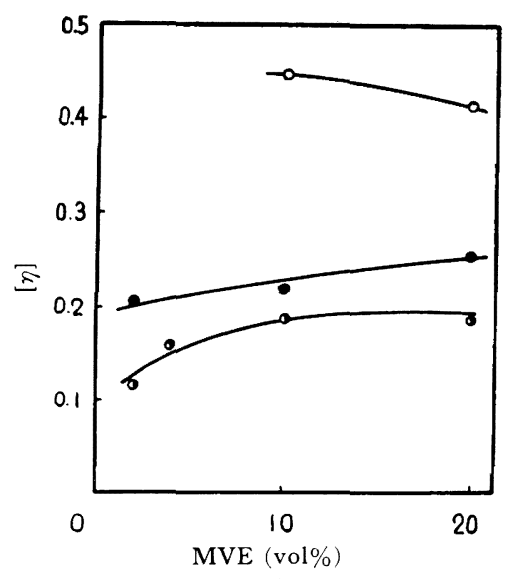

Fig. 7-a

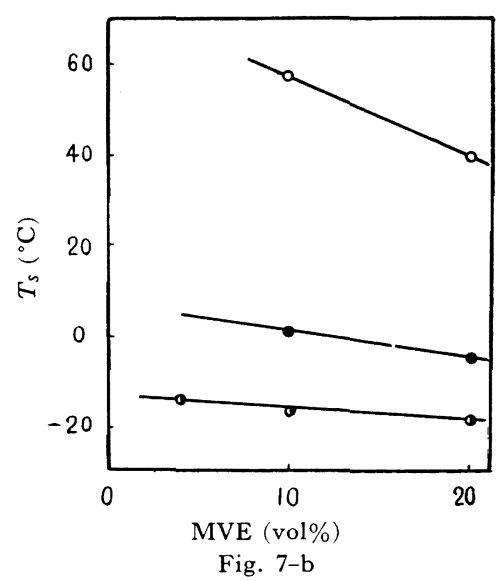

$\mathrm{BF}_{3} \cdot \mathrm{O}\left(\mathrm{C}_{2} \mathrm{H}_{5}\right)_{2}$ catalyst, Toluene solvent, Temperature; $\mathrm{O}:-78^{\circ} \mathrm{C},-50^{\circ} \mathrm{C}, \mathrm{C}$ $-20^{\circ} \mathrm{C}$

Fig. 7 Effects of polymerization temperature on $[\eta]$ (Fig. 7-a) and $T_{s}$ (Fig. 7-b)

された。その結果 IBVEにおいて認められたと同様に, 反応系の誘電率が小さくて低温で重合を行なうと立体規 則性のすぐれたポリマーが得られることが明らかとなっ た。ここでは立体規則性の判定は主として軟化点の測定 で行なったが, 実験の項で述べたように軟化点は立体構 造の差を明瞭に反映していると考えられる。

従来カチオン重合触媒による MVEの立体特異性重合 は, 炭化水素一ハロゲン化炭化水素混合溶媒系による低温 重合が報告されているのみである7。 Schildknecht はこ の重合をハロゲン化炭化水素による活性化重合と名う け, 結晶性の良いポリマーが得られることを述べている。 ここで報告した実験結果ではこの活性化重合に相当する と考えられる $n$-ヘキサン-塩化メチレン系よりも，n-へ キサンートルェン溶媒系で得たポリマーの方が立体規則 


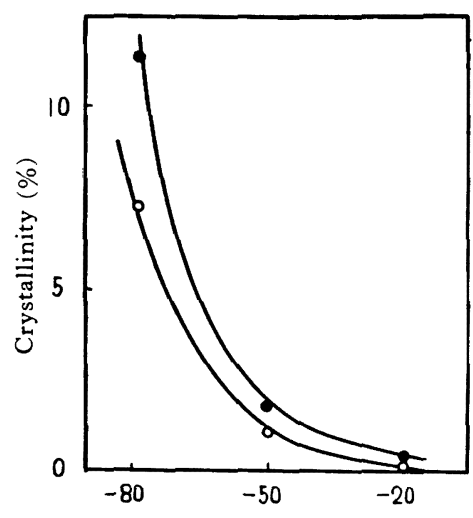

Polymerization temperature $\left({ }^{\circ} \mathrm{C}\right)$

$\mathrm{BF}_{3} \cdot \mathrm{O}\left(\mathrm{C}_{2} \mathrm{H}_{5}\right)_{2}$ catalyst, $:$ MVE 10 vol $\%, \mathrm{C}_{6} \mathrm{H}_{5} \cdot \mathrm{CH}_{3}$ 90 vol\%, O: MVE 20 vol\%, $\mathrm{C}_{6} \mathrm{H}_{5} \cdot \mathrm{CH}_{3} 80$ vol\%

Fig. 8 Relation between polymerization temperature and crystallinity of polymers

性がすぐれていることが明らかとなった。これは先に述 べた誘電率の影響により説明される。

MVE についてはこのように重合条件と立体規則性の 関倸は明確に説明される。しかし EVE はここで行なっ た範囲の重合条件では生成ポリマーの X 線図はすべて 典型的な無定形ポリマーの干涉を与えるにすぎない。一 方生成ポリマーの軟化点は Fig. 5 亿示すよう明らか に変化している。Ziegler 型触媒を用いると結晶性の EVE ポリマーが得られるという報告帛があるから，これ は EVE と MVE の立体規則性の程度に非常な差異があ るのかも知れない。しかしビニルェーテルの置換基がメ チル基とェチル基で, 生長反応の過程で立体規則性にそ れほど差ができるとは考えにくい。軟化点の異なるポリ マーが生じていることは EVE でも立体規則性の異なる ポリマーが生じてはいるが，それが結晶化しないものと 考えるのが妥当であるう。これは $p$-置換スチレン誘導 体が立体規則性は有するが結晶化しないのと同じ関係で あろ5 ${ }^{9)}$ 。こように一般のビニルモノマーの立体規則 性と結晶性の関係を解明することは重合機構の研究の上 からも今後の重要な問題である。

重合温度と PMVE の結晶化度とは Fig. 8 に示すよ らに一定の関係にあることがわかった。ここで求められ ている結晶化度はポリマーを無処理状態で測定した值で あるので最大結晶化度ではないが，ポリマー溶液からゆ っくりと溶媒を蒸発させて得た試料であるので結晶化は かなり進行しているものと考えられる。非常にあらい近 似であるが，ポリエチレンについて求められている最高 結晶化度と isotacticity の関係 ${ }^{10)}$ が PMVE について適 用されるものとする。この二つの非常に大きい仮定を用 いると Fig.8から, 重合温度とポリマーの isotacticity
の割合が求められる。Fordham ${ }^{11)}$ がラジカル重合につ いて研究を行なっているのと同梯に, isotactic 付加と syndiotactic 付加の生長速度定数をそれぞれ $k_{i}$ および $k_{s}$ とすると, $k_{i} / k_{s}$ と isotacticity の関倸は (1) 式で示 される。

$$
\frac{k_{i}}{k_{s}}=\frac{\text { isotacticity }(\%)}{100-\text { isotacticity }(\%)}
$$

また isotactic 付加と syndiotactic 付加の活性化エンタ ルピーおよびェントロピーの差 $\left(\Delta H^{*}\right.$ および $\left.\Delta S^{*}\right)$ と $k_{i} / k_{s}$ との間には $(2)$ 式の関倸が成立する。

$$
\frac{k_{i}}{k_{s}}=e^{\stackrel{\Delta S^{*}}{R}} e^{-\frac{\Delta H^{*}}{R T}}
$$

$$
\begin{array}{ll}
\text { ただし } & \Delta S^{*}=\Delta S_{i}{ }^{*}-\Delta S_{s}{ }^{*} \\
& \Delta H^{*}=\Delta H_{i}{ }^{*}-\Delta H_{s}{ }^{*}
\end{array}
$$

Fig. 8 から求めた $k_{i} / k_{s}$ の対数と重合温度の逆数を図 示すると Fig. 9 が得られる。Nielson の報告によると 結晶化度 0 の場合でも isotacticity は 50 57\% 存在す

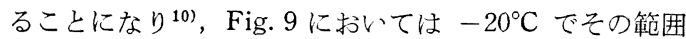
を示した。 $-78,-50^{\circ} \mathrm{C}$ の測定値と $-20^{\circ} \mathrm{C}$ での結晶化 度 0 の範囲での值とから Table 1 の值が得られた。こ れらの值はその導かれた仮定に疑問が多いので絶対值の

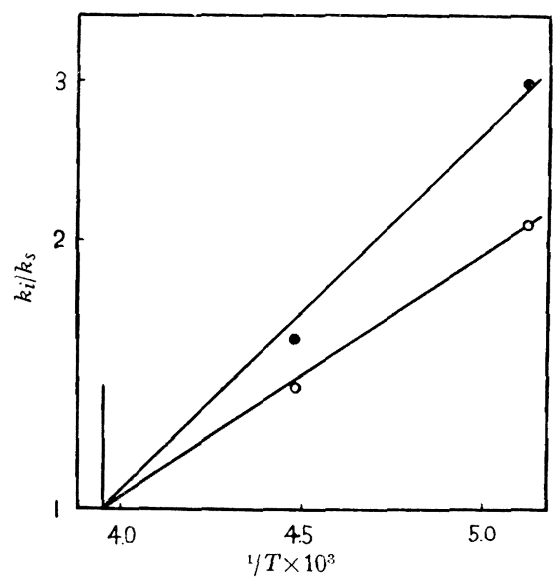

Fig. 9 Arrhenius plot of $k_{i} / k_{s}$ (from Fig. 8)

Table 1 The difference of $\Delta H$ and $\Delta S$ in isotactic and syndiotactic addition (Solvent: Toluene, Catalyst: $\mathrm{BF}_{3} \cdot \mathrm{O}\left(\mathrm{C}_{2} \mathrm{H}_{5}\right)_{2}$ )

\begin{tabular}{c|c|c}
\hline $\begin{array}{c}\text { MVE } \\
\begin{array}{c}\text { concentration } \\
(\text { vol \%) }\end{array}\end{array}$ & $\begin{array}{c}\Delta H^{*} \\
(\mathrm{kcal} / \mathrm{mol})\end{array}$ & $\begin{array}{c}\Delta S^{*} \\
(\mathrm{e} . \mathrm{u} .)\end{array}$ \\
\hline 10 & $-1.6 \pm 0.3$ & $-3.0 \pm 0.8$ \\
20 & $-1.0 \pm 0.3$ & $-1.9 \pm 0.3$ \\
\hline
\end{tabular}


議論は困難であるとしても， $\Delta H^{*}$ が負のかなりの大き さを有していることは明らかである。IBVEについて同 様の方法で得られた $\Delta H^{*}$ の值は MVE で得られた值と ほとんど一致した值が得られた ${ }^{12)}$ 。

Fordham ${ }^{13)}$ はポリ塩化ビニルのポテンシャルエネル ギーより推定して, free endにより生長が進行するラジ カル重合では, syndiotactic な生長の方が isotactic な 生長よりェネルギー的に有利なことを示した。彼はまた 実験結果よりこの值が $0.6 \mathrm{kcal} / \mathrm{mol}$ であることを示し た。Fordham の計算によれば MVE においてもポリ マーのポテンシャルェネルギーからすれば syndiotactic な生長の方が有利であると考えられるのに, 実験結果は 逆の結果を示している。また Fordham の結果によれば 重合系の誘電率が増加すると, ポリマーの立体構造によ るポテンシャルエネルギーの差は少なくなる。したがっ て free end による生長反応では系の誘電率が増すほど 立体構造の差による活性化エネルギーの差は少なくな り, isotactic 付加が起りやすくなってくることになる。 ここでの実験結果はそれとは逆に誘電率の増加によって isotactic 付加が減少している。このことは均一系イオン 重合では free end による重合と異なり, 対イオンの存 在がきわめて重要な役割を演じていることを明確に示し ている ${ }^{14)}$ このことから考えてイオン重合ではモノマー がポリマーの末端に付加する時に立体構造が決定される のであって, 末端のモ, マー単位の立体構造が, 次に攻 揧してくるモノマーが付加してはじめて, ポリマー中の
置換基の相互作用によってその構造を決定するという可 能性は少ないものと思われる。

付 記 本研究の結晶化度の測定ならびに議論をしてい ただいた桜田教授，温品および伊藤両氏に感謝する。本研究は 1960 年 5 月, 第 9 回高分子年次大会 (大阪) で報告した。

\section{文献}

1) 東村敏延, 須永葉子, 岡村誠三：高化, 17, 257 (1960)

2) 岡村誠三, 東村敏延, 山本博一: 高化, 16, 45(1959)

3) たとえば ASTM D 648-45 T

4) 東村敏延, 坚玉恒雄, 岡村誠三 : 高化, 17, 163(1960)

5) W. G. Barb: J. Polymer Sci., 37, 515(1959)

6) 桜田一郎, 温品恭彦, 伊藤泰輔: 未発表

7) C. E. Schildknecht, S. T. Gross and A. O. Zoss : Ind. Eng. Chem., 41, 1998(1949); A. O. Zoss: USP., 2,616,879 (1952)

8) E. J. Vandenberg, R. F. Heck and D. S. Breslow : J. Polymer Sci., 41, 519 (1959)

9) たとえば D. Brawn：J. Polymer Sci., 40, 578 (1959)

10) L. E. Nielsen : J. Appl. Polymer Sci., 2, 351 (1959)

11) J. W. L. Fordham: J. Polymer Sci., 39, 321 (1959)

12) 岡村誠三, 東村敏延, 今西幸男, 児玉恒雄, 中山博 之：高分子討論会 (1960)

13) J. W. L. Fordham, P. H. Burleigh and C. L. Sturn: J. Polymer Sci., 41, 73(1959)

14) 東村敏延, 米沢貞次郎, 岡村誠三, 福井謙一：ibid. 39, 487 (1959)

\title{
Low Temperature-Cationic Polymerization of Alkyl Vinyl Ethers and the Properties of Polymers Obtained
}

\section{Effect of the Polymerization Conditions on the Properties of Polyvinyl Methyl and Ethyl Ether}

\section{By Tsuneo Kodama*, Toshinobu Higashimura* and Seizo Okamura*}

\begin{abstract}
The stereospecific polymerizations of methyl vinyl ether (MVE) and ethyl vinyl ether (EVE) with $\mathrm{BF}_{3} \cdot \mathrm{O}\left(\mathrm{C}_{2} \mathrm{H}_{5}\right)_{2}$ in the homogeneous systems were studied. The degree of stereo-regularity of the polymers obtained was estimated by the determination of softening points. Both by the increase of polymerization temperature and of dielectric constant of the system, the stereoregularities of the polymers obtained decreased. It was found that poly-MVE obtained here showed higher stereoregularity than that reported by Schildknecht, only when it was polymerized in a solvent of low dielectric constant and at low monomer concentration. In polyEVE, one having even high softening point did not give sharp X-ray diffraction pattern. This result may be explained by considering that even high stereoregular polymers are difficult to crystallize in some case. The activation energy difference between isotactic and syndiotactic propagation was estimated, using relation between polymerization temperature and the degree of crystallinity of the polymers obtained. These results were discussed relating with the reaction mechanism.
\end{abstract}

